\title{
Growth Promotion of Parsley (Petroselinum crispum L.) Using Commercial Strains of Trichoderma spp.
}

\author{
Franciely Magalhães Barroso ${ }^{1}$, Paulo Henrique Pereira Costa Muniz ${ }^{1}$, Mariany Dalila Milan ${ }^{1}$, \\ Wanderson Silva dos Santos ${ }^{1}$, Natália Cássia de Faria Ferreira ${ }^{1}$, Fabricio Rodrigues ${ }^{1}$ \\ \& Daniel Diego Costa Carvalho ${ }^{1}$ \\ ${ }^{1}$ Universidade Estadual de Goiás, Câmpus Ipameri, Ipameri, Goiás, Brazil \\ Correspondence: Daniel Diego C. Carvalho, Laboratório de Fitopatologia, Universidade Estadual de Goiás, \\ Rodovia GO 330, km 241, Anel Viário, Setor Universitário, 75780-000, Ipameri, Goiás, Brazil. Tel: \\ 55-643-491-1556. E-mail: daniel.carvalho@ueg.br
}

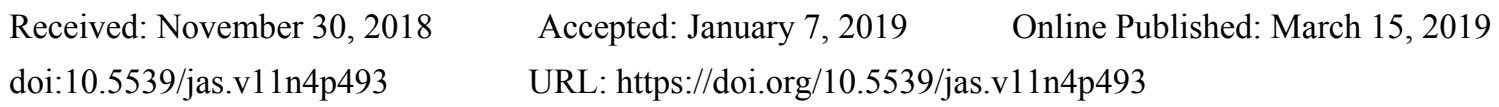

\begin{abstract}
The growth of plants by the use of Trichoderma occurs through distinct mechanisms, among which it can highlight the synthesis of phytohormones and auxins analogues. The objective of this work was to evaluate Trichoderma spp. commercial strains in the promoting seedlings growth and in the productivity of parsley plants. In laboratory assay, seeds of parsley cv. 'Graúda Portuguesa' were treated with $2 \mathrm{~mL}$ of Trichoderma suspension $\left(2.5 \times 10^{8} \mathrm{ml}^{-1}\right.$ conidia per $100 \mathrm{~g}$ of seeds $)$ submitted to growth test until 28 days after sowing (DAS). For the greenhouse experiment, parsley seedlings were transplanted into $3.0 \mathrm{~L}$ pots containing soil, which was previously treated with $5 \mathrm{~mL}$ Trichoderma suspension, totaling $1.5 \times 10^{8}$ conidia per pot. In both, a control without Trichoderma application was included, being arranged in a completely randomized design (CRD). The evaluations were: percentage of germination (PG), root length (RL), shoot length (SL), total length (TL $=$ RL + SL), fresh root mass (FRM), fresh shoot mass (FSM), total fresh mass (TFM = FRM + FSM), root dry mass $(\mathrm{RDM})$, shoot dry mass $(\mathrm{SDM})$, total dry mass $(\mathrm{BIO}=\mathrm{RDM}+\mathrm{SDM})$, root mass ratio $(\mathrm{RMR}=\mathrm{RDM} / \mathrm{BIO})$, shoot mass ratio $(\mathrm{SMR}=\mathrm{SDM} / \mathrm{BIO})$, aerial part/root system retio $(\mathrm{AP} / \mathrm{RS}=\mathrm{SDM} / \mathrm{RDM})$ and productivity at 110 DAS. Althougth no diferences was observed among the Trichoderma treatments and the control about yield, Trichoderma spp. strains provided better TFM (18.98 to $22.92 \mathrm{mg}$ ), BIO (3.37 to $4.31 \mathrm{mg}$ ) and root system superior to the control (14.20 and $2.44 \mathrm{mg}$, respectively) under greenhouse conditions. T. harzianum ESALQ1306 was the better strain in laboratory assyas, suggsting this isolate for applied in the seeds when it aims the promotion of initial growth.
\end{abstract}

Keywords: apiaceae, plant growth promoter, biological control agent

\section{Introduction}

Parsley (Petroselinum crispum) is an herbaceous plant that reaches its importance by commercial use as a condiment, besides the use in the food industry, the parsley has been used in the manufacture of cosmetics and soap, it is a rich crop of antioxidant substances, A, C and K-Complex vitamins (Filgueira, 2008; Dorman et al., 2011; Mahmood et al., 2014). It ia a high-yielding crop, since in an area of only 1.0 hectare, it can be produce $15,000 \mathrm{~kg}$ of parsley per year, providing a turnover of $\$ 16,000$ per hectare per year (Sebrae, 2011; Ceasa, 2017).

Trichoderma spp. is one of the most used fungi in the control of plants pathogens and in the promotion of plant growth due to its versatility of action, such as parasitism, antibiosis and competition, besides acting as inductors of resistance of plants against diseases (Machado et al., 2012; Bae, et al., 2016). The presence of Trichoderma spp. in the soil it makes the nutrients more soluble, allowing a greater and more rapid absorption by the plants, causing increase in the growth of the root system, accompanied by the increase of the green mass (Oliveira et al., 2012). These fungus are found in the rhizosphere and are capable of promoting root growth due to their metabolic production capacity that induces plant cell multiplication (Machado et al., 2012).

The growth of plants by the use of Trichoderma occurs through distinct mechanisms, among which we can highlight the synthesis of phytohormones and analogues of auxins (Martínez-Medina et al., 2014) or the phosphate solubilization provided by the action of these fungi in the rhizosphere of plants (Gonzáles and Fuentes, 2016). In a study using Trichoderma in the treatment of lettuce seeds, Diniz et al. (2006) observed that the 
application of polymers with the addition of antagonistic microorganisms (Trichoderma viride, T. polysporhum and T. stromaticum) at $50 \mathrm{ml} \mathrm{kg}^{-1}$ of seeds using T. viride provided a 99 and $24 \%$ increase in emergence and in the seedling emergence speed index, respectively, besides increasing in $0.112 \mathrm{~g}$ the dry mass production of the aerial part of the plants.

Regarding the parsley crop, special attention is given to the obtaining of fresh mass of the aerial part, since this is the tradable part of the plant. In this context, according to Saito et al. (2009), when using the suspension of Trichoderma ssp. in application via soil, the growth promotion of several plants was verified, mainly in the dry mass increase superior to the treatments without application: bean plant $10 \%$, radish plant $8 \%$, tomato plant $37 \%$, pepper plant $42 \%$ and cucumber plant $93 \%$. Concerinig to parsley, the incremental percentages may be even higher, since Smolinska et al. (2014), when applying fungus of the genus Trichoderma ssp. in the cultivation soil, obtained increases in the mass production of parsley plants of $378 \%$ when compared to the control. The objective of this study as to evaluate five Trichoderma spp. commercial products in promoting seedling growth and in the yield of parsley plants (P. crispum).

\section{Method}

\subsection{Commercial Strains}

The commercial strains evaluated were: Trichoderma harzianum IBLF 006 WP (Ecotrich WP; Ballagro Agro Tecnologia Ltda., Piracaia, SP, Brazil), Trichoderma harzianum ESALQ 1306 (Trichodermil SC, Koppert Biological Systems, Piracicaba, SP, Brazil), Trichoderma asperellum URM 5911 (Quality WG, BioControle Farroupilha Ltda, Patos de Minas, MG, Brazil), Trichoderma harzianum T-22 WG (Trianum WG, Koppert Biological Systems, Piracicaba, SP, Brazil) and Trichoderma harzianum SIMBI T5 (StimuControl SC, Simbiose Agrotechnologia Biológica, Cruz Alta, RS, Brazil).

\subsection{Initial Growth of Parsley Seedlings by Seed Treatment With Suspension of Trichoderma spp.}

Seeds of parsley cv. 'Graúda Portuguesa' were treated with $2 \mathrm{~mL}$ of Trichoderma suspension $\left(2.5 \times 10^{8}\right.$ conidia $\mathrm{ml}^{-1}$ per $100 \mathrm{~g}$ of seeds) (Carvalho et al., 2014). Thus, each treatment had 200 seeds, divided into eight replicates of 25 seeds. After treatment, the seeds were evenly distributed on blotting paper contained in transparent Gerbox-type acrylic boxes $(11 \times 11 \mathrm{~cm})$ and, then, placed into a BOD germinator (Logen Scientific $®)$ for 28 days, according to Brazil (2009). A treatment without inoculation with Trichoderma was included as a control.

At 28 days after sowing (DAS) it was made the following evaluations: percentage of germination (PG), which was obtained by evaluating normal seedlings (absence of necrosis and pathogen in seedlings, seminal and secondary roots without deformations and discounting dead seeds), root length (RL), shoot length (SL), total length $(T L=R L+S L)$, root fresh mass $(R F M)$, shoot fresh mass $(S F M)$, total fresh mass $(T F M=R F M+S F M)$, root dry mass $(\mathrm{RDM})$, shoot dry mass $(\mathrm{SDM})$, total dry mass $(\mathrm{BIO}=\mathrm{RDM}+\mathrm{SDM})$, root mass ratio $(\mathrm{RMR}=$ $\mathrm{RDM} / \mathrm{BIO})$, shoot mass ratio $(\mathrm{SMR}=\mathrm{SDM} / \mathrm{BIO})$ and aerial part/root system ratio $(\mathrm{AP} / \mathrm{RS}=\mathrm{SDM} / \mathrm{RDM})$. To obtain the RDM and SDM, the roots and aerial part were detached and dried separately in a greenhouse at $72{ }^{\circ} \mathrm{C}$ until reaching a constant dry mass.

\subsection{Productivity of Parsley Plants and Their Components by Soil Treatment With Suspension of Trichoderma spp.}

The experiment was conducted in a greenhouse of the Universidade Estadual de Goiás (UEG), Campus Ipameri $\left(17^{\circ} 43^{\prime} 00.38^{\prime \prime} \mathrm{S}, 48^{\circ} 08^{\prime} 40.96^{\prime \prime} \mathrm{W}, 796 \mathrm{~m}\right)$, Brazil. For the installation of the experimente it eas used pots (3.0 L) containing soil and cultural treatments recommended by Filgueira (2008). Then, a dose of $5.0 \mathrm{~mL}$ of Trichoderma suspension was dispensed into each pot with the use of a hand sprayer $(550 \mathrm{~mL})$, totaling $1.5 \times 10^{8}$ conidia per pot. Immediately after spraying, 40-day-old parsley seedlings were transplanted into each pot. The experiment was arranged in a completely randomized design (CRD) with eight replicates (pots) for each treatment (Trichoderma spp. commercial strain). For comparison, a treatment without inoculation of Trichoderma was included as control. At 70 days after transplanting (DAT), the plants were harvested from each pot, and then the productivity in $\mathrm{kg} / \mathrm{ha}$ was measured (considering a population of 580,000 plants/ha for data transformation). The harvested plants were used to measure the same growth components of the previous item (RL, SL, TL, RFM, SFM, TFM, RDM, SDM, BIO, RMR, SMR and AP/RS).

\subsection{Statistical Analyzes}

The data were submitted to analysis of variance (ANOVA) and to the Scott-Knott test $(\mathrm{P} \leq 0.05)$, using SISVAR 5.3 statistical program (Ferreira, 2011). 


\section{Results}

\subsection{Initial Growth of Parsley Seedlings by Seed Treatment With Suspension of Trichoderma spp.}

The strain T. harzianum ESALQ1306 presented increment concerning to the length of the shoot (SL $=1.99 \mathrm{~cm}$ ), $\operatorname{root}(\mathrm{RL}=7.75 \mathrm{~cm})$ and total length $(\mathrm{TL}=9.75 \mathrm{~cm})$, while for the other strains the value of SL, RL and TL ranged from 1.71 to $1.91 \mathrm{~cm} ; 6.58$ to $7.82 \mathrm{~cm}$ and 8.50 to $9.53 \mathrm{~cm}$, respectively (Table 1). For fresh mass variables, $T$. harzianum ESALQ1306 presented higher SFM $(10.86 \mathrm{mg})$, while three strains (ESALQ1306, T-22 and SIMBI-T5) highlighted for RFM and TFM.

Table 1. Percentage of germination (PG), root length (RL), shoot length (SL), total length (TL), root fresh mass (RFM), shoot fresh mass (SFM) and total fresh mass (TFM) of parsley seedlings treated with commercial stains of Trichoderma spp. Ipameri, Goiás, Brazil, $2018^{(1)}$

\begin{tabular}{llllllll}
\hline Treatment & PG $(\%)^{(2)}$ & RL $(\mathrm{cm})$ & SL $(\mathrm{cm})$ & TL $(\mathrm{cm})$ & RFM $(\mathrm{mg})$ & SFM $(\mathrm{mg})$ & TFM (mg) \\
\hline T. harzianum IBLF006 WP & $83.00 \mathrm{a}$ & $7.82 \mathrm{a}$ & $1.71 \mathrm{~b}$ & $9.53 \mathrm{a}$ & $0.85 \mathrm{~b}$ & $6.51 \mathrm{~b}$ & $7.36 \mathrm{~b}$ \\
T. asperellum URM 5911 & $85.00 \mathrm{a}$ & $7.40 \mathrm{~b}$ & $1.70 \mathrm{~b}$ & $9.10 \mathrm{~b}$ & $0.64 \mathrm{~b}$ & $6.39 \mathrm{~b}$ & $7.03 \mathrm{~b}$ \\
T. harzianum ESALQ1306 & $82.50 \mathrm{a}$ & $7.75 \mathrm{a}$ & $1.99 \mathrm{a}$ & $9.74 \mathrm{a}$ & $0.89 \mathrm{~b}$ & $10.86 \mathrm{a}$ & $11.75 \mathrm{a}$ \\
T. harzianum T-22 WG & $81.50 \mathrm{a}$ & $7.25 \mathrm{~b}$ & $1.71 \mathrm{~b}$ & $8.96 \mathrm{~b}$ & $3.07 \mathrm{a}$ & $8.31 \mathrm{~b}$ & $11.38 \mathrm{a}$ \\
T. harzianum SIMBI T5 & $82.00 \mathrm{a}$ & $6.58 \mathrm{c}$ & $1.91 \mathrm{a}$ & $8.49 \mathrm{c}$ & $2.77 \mathrm{a}$ & $7.72 \mathrm{~b}$ & $10.49 \mathrm{a}$ \\
Control & $83.50 \mathrm{a}$ & $6.70 \mathrm{c}$ & $1.93 \mathrm{a}$ & $8.63 \mathrm{c}$ & $0.55 \mathrm{~b}$ & $7.07 \mathrm{~b}$ & $7.62 \mathrm{~b}$ \\
CV $(\%)$ & 5.45 & 25.02 & 26.84 & 20.80 & 27.88 & 19.20 & 19.97 \\
\hline
\end{tabular}

Note. ${ }^{(1)}$ Means followed by the same lowercase letter in the same columns do not statistically differ each other by the Scott Knott test $(\mathrm{P} \leq 0.05) .{ }^{(2)}$ Percentage of emergence at 28 days after sowing.

Regarding the dry mass, newly ESALQ1306 present the better when compared to the others, obtaining $1.77 \mathrm{mg}$ of BIO, against 0.96 to $1.37 \mathrm{mg}$ of the others strains and $0.82 \mathrm{mg}$ for the control (Table 2). For the ratios, $T$. harzianum T-22 WG and $T$. harzianum SIMBI T5 presnented higer RMR values ( 0.46 and 0.47 , respectively). In contrast, these strins presented lower SMR values ( 0.53 and 0.52 , respectively), when compared to the others (SMR ranged from 0.68 to 0.74 ), as well as for AP/RS, with values of 1.12 and 1.14 , while the other treatments obtained higher values, ranging from 2.60 to 2.92 .

Table 2. Root dry mass (RDM), shoot dry mass (SDM), total dry mass (BIO), root mass ratio (RMR), shoot mass ratio (SMR) and aerial part/root system ratio (AP/RS) of parsley seedlings treated with commercial stains of Trichoderma spp. Ipameri, Goiás, Brazil, $2018^{(1)}$

\begin{tabular}{lllllll}
\hline Treatment & RDM $(\mathrm{mg})$ & $\mathrm{SDM}(\mathrm{mg})$ & $\mathrm{BIO}(\mathrm{mg})^{(2)}$ & $\mathrm{RMR}^{(3)}$ & $\mathrm{SMR}^{(4)}$ & $\mathrm{AP} / \mathrm{RS}^{(5)}$ \\
\hline T. harzianum IBLF006 WP & $0.24 \mathrm{c}$ & $0.71 \mathrm{~b}$ & $0.95 \mathrm{c}$ & $0.25 \mathrm{~b}$ & $0.74 \mathrm{a}$ & $2.95 \mathrm{a}$ \\
T. asperellum URM 5911 & $0.28 \mathrm{c}$ & $0.78 \mathrm{~b}$ & $1.06 \mathrm{c}$ & $0.26 \mathrm{~b}$ & $0.73 \mathrm{a}$ & $2.78 \mathrm{a}$ \\
T. harzianum ESALQ1306 & $0.46 \mathrm{~b}$ & $1.30 \mathrm{a}$ & $1.76 \mathrm{a}$ & $0.26 \mathrm{~b}$ & $0.73 \mathrm{a}$ & $2.82 \mathrm{a}$ \\
T. harzianum T-22 WG & $0.63 \mathrm{a}$ & $0.69 \mathrm{~b}$ & $1.32 \mathrm{~b}$ & $0.47 \mathrm{a}$ & $0.52 \mathrm{~b}$ & $1.09 \mathrm{~b}$ \\
T. harzianum SIMBI T5 & $0.62 \mathrm{a}$ & $0.70 \mathrm{~b}$ & $1.32 \mathrm{~b}$ & $0.47 \mathrm{a}$ & $0.53 \mathrm{~b}$ & $1.12 \mathrm{~b}$ \\
Control & $0.27 \mathrm{c}$ & $0.55 \mathrm{c}$ & $0.82 \mathrm{~d}$ & $0.32 \mathrm{~b}$ & $0.67 \mathrm{a}$ & $2.03 \mathrm{a}$ \\
\hline CV (\%) & 17.65 & 9.43 & 8.98 & 14.89 & 7.67 & 22.61 \\
\hline
\end{tabular}

Note. ${ }^{(1)}$ Means followed by the same lowercase letter in the same columns do not statistically differ each other by the Scott Knott test $(\mathrm{P} \leq 0.05) .{ }^{(2)} \mathrm{BIO}=\mathrm{RDM}+\mathrm{SDM} .{ }^{(3)}$ Root mass ratio $(\mathrm{RMR}=\mathrm{RDM} / \mathrm{BIO}) .{ }^{(4)}$ Shoot mass ratio $(\mathrm{SMR}=\mathrm{SDM} / \mathrm{BIO}) .{ }^{(5)}$ Aerial part/root system ratio $(\mathrm{AP} / \mathrm{RS}=\mathrm{SDM} / \mathrm{RDM})$.

\subsection{Productivity of Parsley Plants and Their Components by Soil Treatment With Suspension of Trichoderma} spp.

When evaluating TL, strains T. asperellum URM5911 and T. harzianum ESALQ1306 presented superior results ( 35.0 and $30.5 \mathrm{~cm}$, respectively) to the other treatments, whose values ranged from 25.25 to $27.93 \mathrm{~cm}$, while the control had the lowest TL $(20.43 \mathrm{~cm})$ (Table 3$)$. As for TFM, all Trichoderma strains were superior to the control 
and did not differ from each other, with values ranging from 18.98 to $22.92 \mathrm{mg}$, while the control obtained 14.20 mg.

Table 3. Root length (RL), shoot length (SL), total length (TL), root fresh mass (RFM), shoot fresh mass (SFM) and total fresh mass (TFM) of parsley plants in greenhouse by soil treated with suspension of Trichoderma spp., Ipameri, Goiás, Brazil, $2018^{(1)}$

\begin{tabular}{lllllll}
\hline Treatment & RL $(\mathrm{cm})$ & SL $(\mathrm{cm})$ & TL $(\mathrm{cm})$ & RFM $(\mathrm{mg})$ & SFM $(\mathrm{mg})$ & TFM $(\mathrm{mg})$ \\
\hline T. harzianum IBLF006 WP & $10.50 \mathrm{~b}$ & $14.75 \mathrm{a}$ & $25.25 \mathrm{~b}$ & $10.82 \mathrm{a}$ & $12.10 \mathrm{a}$ & $22.92 \mathrm{a}$ \\
T. asperellum URM 5911 & $22.43 \mathrm{a}$ & $12.57 \mathrm{~b}$ & $35.00 \mathrm{a}$ & $12.08 \mathrm{a}$ & $9.91 \mathrm{a}$ & $21.99 \mathrm{a}$ \\
T. harzianum ESALQ1306 & $18.81 \mathrm{a}$ & $11.69 \mathrm{~b}$ & $30.50 \mathrm{a}$ & $11.93 \mathrm{a}$ & $10.51 \mathrm{a}$ & $22.44 \mathrm{a}$ \\
T. harzianum T-22 WG & $12.93 \mathrm{~b}$ & $14.43 \mathrm{a}$ & $27.36 \mathrm{~b}$ & $9.35 \mathrm{a}$ & $9.63 \mathrm{a}$ & $18.98 \mathrm{a}$ \\
T. harzianum SIMBI T5 & $15.18 \mathrm{~b}$ & $12.74 \mathrm{~b}$ & $27.92 \mathrm{~b}$ & $10.68 \mathrm{a}$ & $10.20 \mathrm{a}$ & $20.88 \mathrm{a}$ \\
Control & $9.93 \mathrm{~b}$ & $10.50 \mathrm{~b}$ & $20.43 \mathrm{c}$ & $5.67 \mathrm{~b}$ & $8.53 \mathrm{a}$ & $14.20 \mathrm{~b}$ \\
CV $(\%)$ & 27.91 & 15.27 & 18.37 & 38.46 & 25.34 & 27.79 \\
\hline
\end{tabular}

Note. ${ }^{(1)}$ Means followed by the same lowercase letter in the same columns do not statistically differ each other by the Scott Knott test $(\mathrm{P} \leq 0.05)$.

Similarly to the TFM, all strains had BIO values higher than the control, whose values varied from 3.38 to 4.37 $\mathrm{mg}$, and the control presented $2.44 \mathrm{mg}$ (Table 4). For the ratios, all strains were similar for RMR, SMR and AP/SR. Detail for the control, which was superior to the Trichoderma strains for SMR and AP/RS. Regarding the yield, there was no difference between the treatments with Trichoderma besides that they were not superior to the control.

Table 4. Root dry mass (RDM), shoot dry mass (SDM), total dry mass (BIO), root mass ratio (RMR), shoot mass ratio (SMR), aerial part/root system ratio (AP/RS) and productivy (YIELD) of parsley plants in greenhouse by soil treated with suspension of Trichoderma spp., Ipameri, Goiás, Brazil, $2018^{(1)}$

\begin{tabular}{|c|c|c|c|c|c|c|c|}
\hline Treatment & RDM (mg) & SDM (mg) & $\mathrm{BIO}(\mathrm{mg})^{(2)}$ & $\mathrm{RMR}^{(3)}$ & $\mathrm{SMR}^{(4)}$ & $\mathrm{AP} / \mathrm{RS}^{(5)}$ & YIELD $\left(\mathrm{kg} \mathrm{ha}^{-1}\right)$ \\
\hline T. harzianum IBLF006 WP & $2.36 \mathrm{a}$ & $2.01 \mathrm{a}$ & $4.37 \mathrm{a}$ & $0.54 \mathrm{a}$ & $0.45 \mathrm{~b}$ & $0.85 \mathrm{~b}$ & $7019 \mathrm{a}$ \\
\hline T. asperellum URM 5911 & $2.60 \mathrm{a}$ & $1.61 \mathrm{a}$ & $4.21 \mathrm{a}$ & $0.61 \mathrm{a}$ & $0.39 \mathrm{~b}$ & $0.61 \mathrm{~b}$ & $5752 \mathrm{a}$ \\
\hline T. harzianum ESALQ1306 & $2.28 \mathrm{a}$ & $1.82 \mathrm{a}$ & $4.10 \mathrm{a}$ & $0.55 \mathrm{a}$ & $0.44 \mathrm{~b}$ & $0.79 \mathrm{~b}$ & $6100 \mathrm{a}$ \\
\hline T. harzianum T-22 WG & $1.66 \mathrm{~b}$ & $1.71 \mathrm{a}$ & $3.37 \mathrm{a}$ & $0.49 \mathrm{a}$ & $0.50 \mathrm{~b}$ & $1.03 \mathrm{~b}$ & $5589 \mathrm{a}$ \\
\hline T. harzianum SIMBI T5 & $1.83 \mathrm{~b}$ & $1.74 \mathrm{a}$ & $3.57 \mathrm{a}$ & $0.51 \mathrm{a}$ & $0.48 \mathrm{~b}$ & $0.95 \mathrm{~b}$ & $5916 \mathrm{a}$ \\
\hline Control & $1.08 \mathrm{c}$ & $1.36 \mathrm{a}$ & $2.44 \mathrm{~b}$ & $0.44 \mathrm{a}$ & $0.55 \mathrm{a}$ & $1.25 \mathrm{a}$ & 4948 a \\
\hline $\mathrm{CV}(\%)$ & 29.61 & 28.00 & 23.35 & 16.42 & 19.82 & 36.38 & 25.34 \\
\hline
\end{tabular}

Note. ${ }^{(1)}$ Means followed by the same lowercase letter in the same columns do not statistically differ each other by the Scott Knott test $(\mathrm{P} \leq 0.05) .{ }^{(2)} \mathrm{BIO}=\mathrm{RDM}+\mathrm{SDM} .{ }^{(3)}$ Root mass ratio $(\mathrm{RMR}=\mathrm{RDM} / \mathrm{BIO}) .{ }^{(4)}$ Shoot mass ratio $(\mathrm{SMR}=\mathrm{SDM} / \mathrm{BIO}) .{ }^{(5)}$ Aerial part/root system ratio $(\mathrm{AP} / \mathrm{RS}=\mathrm{SDM} / \mathrm{RDM})$.

\section{Discussion}

In laboratory assays, strain ESALQ1306 presented increment such as SL, RL and TL. This increase corroborates with other studies carried out with the same strain, wherein applications of ESALQ1306 on substrate in a greenhouse increased the root length of 'Jalo Precoce' bean plants for $12 \%$ at 11 DAS (Carvalho et al., 2011). The effect on root growth was expected, since T. harzianum establishes a system of fungus-plant interaction, which results in the stimulation lateral roots development (Harman et al., 2000; Machado et al., 2012). Regarding the fresh mass variables, T. harzianum ESALQ1306 presented higher FMS (10.86 mg), while three strains (ESALQ1306, T-22 and SIMBI-T5) highlighted for RFM and TFM. This fact can be explained by the interaction of Trichoderma and the plant, which promotes changes in root architecture, increasing its specific area, due to the colonization of the fungus, which leads to the alteration of plant physiology, resulting in a greater efficiency in the absorption and solubilization of nutrients such as phosphate and micronutrient availability (Harman et al., 2012). 
Similarly, Smolinska et al. (2014) reported that the addition of Trichoderma to the soil increasied the fresh mass of parsley plants at ratio of $378 \%$ when compared to the control. This evente may be correlated with the increase of water and nutrient absorption capacity and plant health, consequently, increasing the plant fresh mass (Machado et al., 2012). The difference found for dry mass between treatments with Trichoderma and the control can be explained due to the beneficial effects caused directly or indirectly by the fungus. As for the difference between the isolates, it is recorded that the increases in dry matter production may vary according to the Trichoderma isolate and the culture (Souza Pedro et al., 2012). As for the reasons, T. harzianum T-22 WG and T. harzianum SIMBI T5 presented higher values for RMR. However, in contrast, these two strains showed lower values of SMR, as well as for AP/RS, suggesting these two strains for stimulating root growth in laboratory.

When evaluating Trichoderma spp. in greenhouse, T. asperellum URM5911 and T. harzianum ESALQ1306 presented superior TL results. Similarly, in a study lead by Heredia et al. (2003), it was obtained an average of $28.41 \mathrm{~cm}$ of parley plants height, without use of growth promoter, inferior value when compared to the height of plants using strains of Trichoderma spp. (up to $35.0 \mathrm{~cm}$, as can be seen in Table 3). In this study, attempts have been made to T. asperellum URM 5911, which obtained a different result in laboratory test and greenhouse, whose can behave in opposite way, depending on the environment in which they are exposed (Akrami et al., 2011). Concerning the total fresh mass and total dry mass, all plants grown in soil treated with Trichoderma, do not differed from each other, it is evident that the commercial strains of Trichoderma were essential to obtain the TFM and BIO superior to the control. An explanation for this fact could rely on the study carried out by Oliveira et al. (2018), where wheat plants inoculated with different Trichoderma strains, presented higher values of total fresh mass and total dry mass when compared to the control. This is, it presented greater roost system development and as consequence, increase in the fresh mass in several parts of the plant. In addition, the effect of Trichoderma spp. in plant growth is dependent on several factors, from the antagonistic action to phytopathogenic agents to the maximization of absorption, translocation of nutrients and promotion of plant growth (Souza Pedro et al., 2012). Regarding reasons, all strains shown similar behavior as the RMR, SMR and AP/RS. It is noteworthy that the control was superior to the Trichoderma strains for SMR and AP/RS. Probably this fact it is associated to the biomass allocation to the root system, through the communication between plant and microorganism, so stimulating the development of the roots in search for nutrients in the soil (Missio et al., 2018).

The yield results of this study (4948-7019 $\mathrm{kg} \mathrm{ha}^{-1}$ ) were satisfactory when compared to the result obtained by Heredia et al. (2003), which received $5800 \mathrm{~kg} \mathrm{ha}^{-1}$. Thus, concerning to salsa yield, there was no difference between treatments, including witness. However, the use of these products to induce growth and production can not be disregarded, since they have great potential for the biocontrol of soil borne plant pathogens, such as the ESALQ1306 strain (Carvalho et al., 2015).

\section{Conclusion}

T. harzianum T-22 WG and T. harzianum SIMBI T5 presented higher values for RMR, suggesting these two strains for stimulating root growth in laboratory. However, T. harzianum ESALQ1306 was the better strain in laboratory assyas (RL, SL and TL) suggsting this isolate for applied in the seeds when it aims the promotion of initial growth.

Trichoderma spp. strains provided better TFM, BIO and root system of parsley plants when applied on soil under greenhouse conditions.

\section{References}

Akrami, M., Golzary, H., \& Ahmadzadeh, M. (2011). Evaluation of different combinations of Trichoderma species for controlling Fusarium rot of lentil. African Journal of Biotechnology, 10(14), 2653-2658. https://doi.org/10.5897/AJB10.1274

Bae, S. J., Mohanta, T. K., Chung, J. Y., Ryu, M., Park, G., Shim, S., ... Bae, H. (2016). Trichoderma metabolites as biological control agents against Phytophthora pathogens. Biological Control, 92, 128-138. https://doi.org/10.1016/j.biocontrol.2015.10.005

Brazil, Ministério da Agricultura e Reforma Agrária. (2009). Regras para análise de sementes (p. 364). Brasília: SNDA/ DNDV/CLAV.

Carvalho, D. D. C., Geraldine, A. M., Lobo Junior, M., \& Mello, S. C. M. (2015). Biological control of white mold by Trichoderma harzianum in common bean under field conditions. Pesquisa Agropecuária Brasileira, 50(12), 1220-1224. https://doi.org/10.1590/S0100-204X2015001200012 
Carvalho, D. D. C., Lobo Junior, M., Martins, I., Inglis, P. W., \& Mello, S. C. M. (2014). Biological control of Fusarium oxysporum f. sp. phaseoli by Trichoderma harzianum and its use for common bean seed treatment. Tropical Plant Pathology, 39(5), 384-391. https://doi.org/10.1590/S198256762014000500005

Carvalho, D. D. C., Mello, S. C. M., Lobo Junior, M., \& Geraldine, A. M. (2011). Biocontrol of seed pathogens and growth promotion of common bean seedlings by Trichoderma harzianum. Pesquisa Agropecuária Brasileira, 46(8), 822-828. https://doi.org/10.1590/S0100-204X2011000800006

Ceasa (Centrais de abastecimento do Estado de Goiás). (2017). Cotações. Retrieved from http://www.ceasa.go. gov.br/pagina/ver/9674/cotacoes

Diniz, K. A., Oliveira, J. A. O., Guimarães, R. M., Carvalho, M. L. M., \& Machado, J. C. (2006). Incorporação de microrganismos, aminoácidos, micronutrientes e reguladores de crescimento em sementes de alface pela técnica de peliculização. Revista Brasileira de Sementes, 28(3), 37-43. https://doi.org/10.1590/S0101-31222 006000300006

Dorman, H. J., Lantto, T. A, Raasmaja, A., \& Hiltunen, R. (2011). Antioxidant, pro-oxidant and cytotoxic properties of parsley. Food \& Function, 2, 328-337. https://doi.org/10.1039/c1 fo10027k

Ferreira, D. F. (2011). Sisvar: A computer statistical analysis system. Ciência e Agrotecnologia, 35(6), 1039-1042. https://doi.org/10.1590/S1413-70542011000600001

Filgueira, F. A. R. (2008). Novo manual de olericultura: Agrotecnologia moderna na produção e comercialização de hortaliças (3rd ed., p. 421). Viçosa: Editroa UFV.

González, H., \& Fuentes, N. (2016). Mecanismo de acción de cinco microorganismos promotores de crecimiento vegetal. Revista de Ciencias Agrícolas, 34(1), 17-31. https://doi.org/10.22267/rcia.173401.60

Harman, G. E. (2000). Myths and dogmas of biocontrol changes in perceptions derived from research on Trichoderma harzinum T-22. Plant Disease, 84(4), 377-393. https://doi.org/10.1094/PDIS.2000.84.4.377

Harman, G. E., Herrera, A. H. E., Horwitz, B. A., \& Lorito, M. (2012). Special issue: Trichoderma-from Basic Biology to Biotechnology. Microbiology, 158(1), 01-02. https://doi.org/10.1099/mic.0.056424-0

Heredia, Z., Nestor, A., Vieira, M. C., Weismann, M., \& Lourenço, A. L. F. (2003). Produção e renda bruta de cebolinha e de salsa em cultivo solteiro e consorciado. Horticultura Brasileira, 21(3), 574-577. https://doi.org/10.1590/S0102-05362003000300032

Machado, D. F. M., Parzianello, R. F., Silva, A. C. F., \& Antoniolli, Z. I. (2012). Trichoderma no Brazil: O Fungo e Bioagente. Revista de Ciências Agrárias, 35(1), 274-288.

Mahmood, S., Hussain, S., \& Malik, F. (2014). Critique of medicinal conspicuousness of Parsley (Petroselinum crispum): A culinary herb of Mediterranean region. Pakistan Journal of Pharmaceutical Sciences, 27(1), 193-202.

Martínez-Medina, A., Del Mar, M. A., Pascual, J. A., Saskia, C. M., \& Van, W. S. C. (2014). Phytohormone Profiles Induced by Trichoderma Isolates Correspond with Their Biocontrol and Plant Growth-Promoting Activity on Melon Plants. Journal of Chemical Ecology, 40(7), 804-815. https://doi.org/10.1007/s10886 $-014-0478-1$

Missio, E. L., Muniz, M. F., Brum, D. L., Schultz, C. P., \& Cargnelutti Filho, A. (2018). Produção de mudas de Parapiptadenia rigida pelo tratamento de sementes com Trichoderma (Hypocreales) e polímero. Caderno de Pesquisa, 30(1), 21-32. https://doi.org/10.17058/cp.v30i1.11180

Oliveira, J. B., Muniz, P. H. P. C., Peixoto, G. H. S., Oliveira, T. A. S., Duarte, E. A. A., Rodrigues, F., \& Carvalho, D. D. C. (2018). Promotion of Seedling Growth and Production of Wheat by Using Trichoderma spp. Journal of Agricultural Science, 10(8), 267-276. https://doi.org/10.5539/jas.v10n8p267

Saito, L. R., Sales, L. L. S. R., Martinckoski, L., Royer, R., Ramos, M. S., \& Reffati, T. (2009). Aspectos dos efeitos do fungo Trichoderma spp. no biocontrole de patógenos de culturas agrícolas. Pesquisa Aplicada \& Agrotecnologia, 3(2), 203-208.

Sebrae (Serviço Brasileiro de Apoio às Micro e Pequenas Empresas). (2011). Cartilha cheiro verde passo a passo. Retrieved from http://uc.sebrae.com.br/files/institutional-ublication/pdf/cartilha_cheiro_verde_passo _a_passo.pdf 
Smolinska, U., Kowalska, B., Kowalczyk, W., \& Szczech, M. (2014). The use of agro-industrial wastes as carriers of Trichoderma fungi in the parsley cultivation. Scientia Horticulturae, 179(24), 1-8. https://doi.org/10.1016/j.scienta.2014.08.023

Souza Pedro, E. A., Harakava, R., Lucon, C. M. M., \& Guzzo, S. D. (2012). Promoção do crescimento do feijoeiro e controle da antracnose por Trichoderma spp. Pesquisa Agropecuária Brasileira, 47(11), 1589-1595. https://doi.org/10.1590/S0100-204X2012001100005

\section{Copyrights}

Copyright for this article is retained by the author(s), with first publication rights granted to the journal.

This is an open-access article distributed under the terms and conditions of the Creative Commons Attribution license (http://creativecommons.org/licenses/by/4.0/). 